Nepal Journal of Science and Technology 12 (2011) 23 - 28

\title{
Effect of Integrated Nutrient Management on the Growth, Yield and Soil Nutrient Status in Tomato
}

\author{
Prativa K.C. and B.P. Bhattarai \\ Himalayan College of Agricultural Sciences and Technology, Gaththaghar, Bhaktapur \\ e-mail: prativa.kc@gmail.com
}

\begin{abstract}
A field experiment was conducted at the Integrated Research Farm of Himalayan College of Agricultural Sciences and Technology (HICAST) at Bandegaon, Lalitpur, Nepal during 2009 to scrutinize the effect of Integrated Nutrient Management (INM) on the growth, yield and soil nutrient status to tomato (Lycopersicon lycopersicum (L.) Karsten). Following a randomized complete block design, 9 treatments with 3 replications were maintained. The study revealed that the integration of organic manures in combination with inorganic fertilizers was found significant in improving the overall plant growth, yield and soil macro nutrient status than the sole application of either of these nutrients. Maximum plant height and number of leaves per plant were observed with treatment $16.66 \mathrm{mt} / \mathrm{ha}$ $\mathrm{FYM}+8.33 \mathrm{mt} / \mathrm{ha}$ Vermicompost + NPK. The earlier of days to $50 \%$ flowering was observed in treatment $20 \mathrm{mt} / \mathrm{ha}$ FYM. Highest number of fruit clusters, maximum fruit weight and fruit yield $(25.74 \mathrm{mt} / \mathrm{ha})$ were recorded in treatment $16.66 \mathrm{mt} / \mathrm{ha} \mathrm{FYM} \mathrm{+} 8.33 \mathrm{mt} / \mathrm{ha}$ Vermicompost $+\mathrm{NPK}$. The $\mathrm{pH}$ value was found near to neutral in treatment $10 \mathrm{mt} / \mathrm{ha}$ vermicompost. Similarly, the maximum organic matter percentage was also recorded in treatment $10 \mathrm{mt} / \mathrm{ha}$ vermicompost. The highest available nitrogen, phosphorus and potassium were found in treatment $1 / 2 \mathrm{NPK}+15 \mathrm{mt} /$ ha vermicompost.
\end{abstract}

Key words: NPK, vermicompost, FYM, soil nutrients, tomato

\section{Introduction}

Tomato (Lycopersicon lycopersicum (L.) Karsten) is one of the major income generating vegetable crops of Nepal in terms of production and cultivated area. It occupies an area of 15,572 ha of land and its annual production is 2,19,194 $\mathrm{mt}$ (VDD 2009). Tomato has acquired the status of world's most popular vegetable crop due to its wider adaptability to various agroclimatic conditions. At present, tomatoes rank third, next to potato and sweet potato in terms of global vegetable production (FAO 2002). However, the average yield in Nepal is quite low compared to the average yield of Asia (2,430 mt/ha) and world (26.74 $\mathrm{mt} / \mathrm{ha}$ ) (FAO 2003).
Fertilizers no doubt have played a key role in agriculture production and have changed Asia from a region of food scarcity to food sufficiency. But the fertilizer production is largely dependent on the nonrenewable energy sources. Consequently, the use of organic manures to supplement fertilizers has declined substantially. To achieve compliance with an increasing amount of agricultural, environmental, legislative and economical constraints, a well defined fertilizer strategy needs to be developed which would lead to optimization of nutrient use, crop production and quality. Thus, the integrated nutrient use of organic and inorganic fertilizers has assumed great significance in recent years. 
Organic manures in proper blend with chemical fertilizers will predictably support crop growth (Kumar et al. 2009). Kumar and Sharma (2004) reported that application of organic manures with NPK were found best in obtaining higher values for yield and available macronutrients (NPK) in both tomato and carrot. As little information is available on the combined effect of NPK and organic manures on tomato, this study was made to find out the effect of INM on the soil nutrient status of tomato.

\section{Methodology}

The study was conducted during 2009 at the Integrated Research Farm of HICAST at Bandegaon, Lalitpur. Yash variety of tomato was selected. Each experimental plot was $2.5 \times 2 \mathrm{~m}^{2}$. One month old tomato seedlings were transplanted at a distance of $60 \times 45 \mathrm{~cm}$. The experiment was laid out in a randomized complete block design with 3 replications. There were 9 treatments: $\mathrm{T}_{1}=20 \mathrm{mt} / \mathrm{ha}, \mathrm{T}_{2}=$ Half of the recommended $\mathrm{NPK}+30 \mathrm{mt} / \mathrm{ha} \mathrm{FYM}, \mathrm{T}_{3}=$ Three fourths of the recommended NPK $+25 \mathrm{mt} / \mathrm{ha}, \mathrm{T}_{4}=10 \mathrm{mt} / \mathrm{ha}$ Vermicompost, $\mathrm{T}_{5}=$ Half of the recommended NPK + $15 \mathrm{mt} /$ ha Vermicompost, $\mathrm{T}_{6}=$ Three fourths of the recommended NPK $+12.5 \mathrm{mt} /$ ha Vermicompost, $\mathrm{T}_{7}=$ $16.66 \mathrm{mt} / \mathrm{ha} \mathrm{FYM} \mathrm{+} 8.33 \mathrm{mt} / \mathrm{ha}$ Vermicompost + NPK, $\mathrm{T}_{8}=$ Recommended NPK (100: 80: $\left.60 \mathrm{~kg} / \mathrm{ha}\right), \mathrm{T}_{9}=$ Control (no organic manures and inorganic fertilizers). The treatments were tested at 5\% level of significance.

The required amounts of fertilizers and manures were weighed by a weighing balance separately. Organic manures were applied in the field an hour before transplantation by mixing properly with soil. Incase of chemical fertilizers, half of the total amount was basally applied and the remaining half was in circular furrows.

The observations in respect to increment in plant height, number of leaves per plant, days to $50 \%$ flowering, number of fruit clusters per plant, fruit weight, and yield per plant were recorded in the field while the estimations and analysis of available nitrogen, available phosphorus, and available potash were done in the soil laboratory of HICAST.

\section{Determination of growth and yield of tomato}

Plant height was measured from the ground level to the growing point and the observation was recorded at the end of the growing period for each treatment and was expressed in centimeters. Similarly, effective leaves were counted and the mean was calculated. The number of days to 50\% flowering was counted for all treatments. The average was then calculated and recorded. The total number of fruit clusters was counted for each treatment and then the mean was calculated and recorded. The observations on fruit weight for each treatment were recorded at the time of harvest. After each harvest, the individual fruits were weighed and the data on fruit weight was summed up and expressed in gram. The observations on yield were recorded at the time of harvesting. After harvesting, the tomato fruits were weighed from each treatment plots.

\section{Determination of soil macronutrient status}

Soil samples representing $30 \mathrm{~cm}$ deep soil was collected from the experimental plot during the month of September. Three samples from each plot were taken and mixed to form one composite sample and then dried in shade and sieved through $2 \mathrm{~mm}$ bronze sieve and stored in cloth bags for further analysis. Available N was determined by Kjeldahl method (Jackson 1975), available $\mathrm{P}$ was determined by Modified Olsen's method (Olsen et al. 1954) and available K was determined by Ammonium acetate method (Hanway $\&$ Heidal 1952).

\section{Results and Discussion Growth \\ Plant height}

Maximum increment in plant height $(116.16 \mathrm{~cm})$ was observed with $\mathrm{T}_{7} 16.66 \mathrm{mt} / \mathrm{ha} \mathrm{FYM}+8.33 \mathrm{mt} / \mathrm{ha}$ Vermicompost +NPK (Table 1). The better efficiency of organic manures in combination with inorganic fertilizers might be due to the fact that the organic manures would have provided the micronutrients in an optimum range to the plant. Application of organic manures would have helped in enhancing the metabolic activity through the supply of such important micronutrients in the early growth phase which in turn must have encouraged the overall growth. Several other workers have also reported the highest plant growth due to the combined application of organic manures and chemical fertilizers in tomato (Alam 2006, Azad 2000). 


\section{Number of leaves per plant}

Maximum number of leaves per plant was recorded in treatment $16.66 \mathrm{mt} / \mathrm{ha} \mathrm{FYM} \mathrm{+8.33} \mathrm{mt/ha} \mathrm{vermicompost}$ + NPK (Table 1). Data of the present study clearly indicated that vegetative growth was higher in plots that received integrated (organic and inorganic) nutrient supply. This might be due to the fact that the application of NPK, FYM and vermicompost provided adequate $\mathrm{N}$ which is associated with high photosynthetic activity and vigorous vegetative growth. Combination of organic and inorganic fertilizers significantly increased the number of leaves in cabbage (Kabir 1998, Azad 2000)

Table 1. Effect of integrated nutrient management on the growth of tomato

\begin{tabular}{|c|c|c|}
\hline Treatments & Plant height (cm) & $\begin{array}{c}\text { Number of leaves per } \\
\text { plant }\end{array}$ \\
\hline $\mathrm{T}_{1}(20 \mathrm{mt} / \mathrm{ha})$ & 103.03 & 102.75 \\
\hline $\mathrm{T}_{2}$ (Half of the recommended NPK $+30 \mathrm{mt} / \mathrm{ha} \mathrm{FYM}$ ) & 114.43 & 107.33 \\
\hline $\mathrm{T}_{3}$ (Three fourths of the recommended NPK $+25 \mathrm{mt} / \mathrm{ha}$ & 108.70 & 111.33 \\
\hline $\mathrm{T}_{4}(10 \mathrm{mt} / \mathrm{ha}$ Vermicompost $)$ & 104.30 & 104.50 \\
\hline $\mathrm{T}_{5}$ (Half of the recommended NPK $+15 \mathrm{mt} / \mathrm{ha}$ Vermicompost & 114.60 & 111.33 \\
\hline $\begin{array}{l}\mathrm{T}_{6} \text { (Three fourths of the recommended NPK }+12.5 \mathrm{mt} / \mathrm{ha} \\
\text { Vermicompost }\end{array}$ & 110.70 & 109.33 \\
\hline $\mathrm{T}_{7}(16.66 \mathrm{mt} / \mathrm{ha} \mathrm{FYM}+8.33 \mathrm{mt} / \mathrm{ha}$ Vermicompost $+\mathrm{NPK}$ & 116.16 & 114.50 \\
\hline $\mathrm{T}_{8}$ (Recommended NPK (100: $\left.80: 60 \mathrm{~kg} / \mathrm{ha}\right)$ & 103.85 & 105.50 \\
\hline $\mathrm{T}_{9}$ (Control) & 93.90 & 94.75 \\
\hline $\mathrm{CD}(0.05)$ & 1.44 & 3.76 \\
\hline
\end{tabular}

\section{Days to $50 \%$ flowering}

It is evident from the dada given in Table 2 that the earliness in days to $50 \%$ flowering (26.33) was recorded in treatment $20 \mathrm{mt} / \mathrm{ha}$ FYM. The earliness in flowering could be attributed to the faster enhancement of vegetative growth and storing sufficient reserved food materials for differentiation of buds into flower buds whereas the delayed flowering by the inorganic fertilizer treatment could be due to extended vegetative phase of the plant by the availability of inorganic nitrogen. These results are in close conformity of the findings of Renuka and Ravi Shankar (1998).

\section{Number of fruit clusters per plant}

Maximum number of fruit clusters (6.90) was recorded with $\mathrm{T}_{7} 16.66 \mathrm{mt} / \mathrm{haFYM}+8.33 \mathrm{mt} /$ ha Vermicompost + NPK (Table 2). This confirms the significance of conjunctive use of chemical and organic fertilizers than the individual one which might be due to the solubilization effect of plant nutrients by the addition of FYM and Vermicompost leading to increased uptake of NPK. Bahadur et al. (2004) also showed that application of organic manures combined with recommended dose of inorganic fertilizers showed superior performance in tomato.

\section{Fruit weight}

The maximum fruit weight $(52.8 \mathrm{~g})$ was recorded in $\mathrm{T}_{7}$ $16.66 \mathrm{mt} / \mathrm{ha} \mathrm{FYM}+8.33 \mathrm{mt} / \mathrm{ha}$ Vermicompost +NPK (Table 2). This might be due to solubilization effect of plant nutrients by the addition of FYM and Vermicompost leading to increased uptake of NPK as was reported by Subbiah et al. (1982).

\section{Fruit Yield}

Tomato fruit yield was affected significantly by different treatments. Maximum yield (25.74 mt/ha) was observed in $\mathrm{T}_{7} 16.66 \mathrm{mt} / \mathrm{ha} \mathrm{FYM}+8.33 \mathrm{mt} / \mathrm{ha}$ Vermicompost + NPK (Table 2). The reasons for increased fruit yield by the application of NPK with FYM and Vermicompost leading to increased uptake of NPK. The results are in agreement with the findings of Kumaran et al. (1995) who recorded an increase in fruit yield by the application of NPK with FYM and Vermicompost. 
Nepal Journal of Science and Technology 12 (2011) 23-28

Table 2. Effect of integrated nutrient management on the yield of tomato

\begin{tabular}{|c|c|c|c|c|}
\hline Treatments & $\begin{array}{l}\text { Days to } 50 \% \\
\text { flowering }\end{array}$ & $\begin{array}{c}\text { Number of } \\
\text { clusters per } \\
\text { plant }\end{array}$ & $\begin{array}{c}\text { Individual } \\
\text { fruit weight } \\
(\mathrm{g})\end{array}$ & Yield (mt/ha) \\
\hline $\mathrm{T}_{1}(20 \mathrm{mt} / \mathrm{ha})$ & 26.33 & 5.98 & 37.45 & 21.70 \\
\hline $\mathrm{T}_{2}(1 / 2 \mathrm{NPK}+30 \mathrm{mt} / \mathrm{ha} \mathrm{FYM})$ & 27.00 & 6.54 & 43.89 & 24.18 \\
\hline $\mathrm{T}_{3}(3 / 4 \mathrm{NPK}+25 \mathrm{mt} / \mathrm{ha}$ & 28.00 & 6.36 & 49.10 & 25.11 \\
\hline $\mathrm{T}_{4}(10 \mathrm{mt} / \mathrm{ha}$ Vermicompost $)$ & 26.66 & 6.18 & 40.82 & 22.07 \\
\hline $\begin{array}{l}\mathrm{T}_{5} \quad(1 / 2 \underset{\mathrm{NPK}}{\mathrm{N}}+15 \mathrm{mt} / \mathrm{ha} \\
\text { Vermicompost }\end{array}$ & 27.33 & 6.58 & 49.41 & 25.29 \\
\hline $\begin{array}{l}\mathrm{T}_{6}(3 / 4 \quad \mathrm{NPK}+12.5 \mathrm{mt} / \mathrm{ha} \\
\text { Vermicompost }\end{array}$ & 28.66 & 6.69 & 45.87 & 24.22 \\
\hline $\begin{array}{l}\mathrm{T}_{7}(16.66 \mathrm{mt} / \mathrm{ha} \mathrm{FYM}+8.33 \mathrm{mt} / \mathrm{ha} \\
\text { Vermicompost }+\mathrm{NPK}\end{array}$ & 27.33 & 6.90 & 52.80 & 25.74 \\
\hline $\begin{array}{l}\mathrm{T}_{8} \text { (Recommended NPK (100: } 80: 60 \\
\mathrm{~kg} / \mathrm{ha})\end{array}$ & 29.60 & 6.04 & 39.33 & 21.70 \\
\hline $\mathrm{T}_{9}$ (Control) & 31.66 & 5.06 & 33.82 & 19.07 \\
\hline $\mathrm{CD}(0.05)$ & 1.67 & 0.14 & 7.82 & 2.25 \\
\hline
\end{tabular}

\section{Available macronutrients}

The different treatments had significant influence on the available phosphorus in the soil. Maximum available Nitrogen $(382.80 \mathrm{~kg} / \mathrm{ha})$ was observed in treatment half of the recommended NPK $+15 \mathrm{mt} / \mathrm{ha}$ $\left(\mathrm{T}^{5}\right)$ (Table 3). Inspite of using chemical fertilizers the available N was found low in NPK treated soil which might be due to leaching and volatilization losses, whereas in organic manure applied soil the applied manure holds the nutrients and retains losses. Mixing of $\mathrm{N}$ fertilizer and organic manures might have reduced the nitrogen losses, improved the fertilizer use efficiency thus increasing the availability of N. Bahadur et al. (2004) also reported that nitrogen uptake by okra increased significantly in treatments which received integrated nutrition. The maximum available phosphorus $(100.40 \mathrm{~kg} / \mathrm{ha})$ was recorded in treatment half of the recommended NPK $+15 \mathrm{mt} / \mathrm{ha}\left(\mathrm{T}^{5}\right)$ (Table 3). This may be attributed to the fact that vermicompost in combination with FYM and full dose of NPK might have helped in the solubilization of fixed P to soluble form making it easily available to the plant. The results are in conformity with the findings of Prasad and Rokima (1992) who reported the increase in available $\mathrm{P}$ content with the integrated use of organic, inorganic and biofertilizers. Different treatments had significant influence on available potassium in the soil. Maximum available $\mathrm{P}$ content $(230.80 \mathrm{~kg} / \mathrm{ha})$ was recorded in treatment half of the recommended NPK $+15 \mathrm{mt} / \mathrm{ha}\left(\mathrm{T}^{5}\right)$ (Table 3 ). Increment in potassium uptake was observed in almost all the integrated nutritional treatments over the sole chemical fertilization. Similar results were reported by Bahadur and Singh et al. (2004). This might be due to enhancement in $\mathrm{K}$ availability by shifting the equilibrium among the forms of $\mathrm{K}$ from relatively exchangeable $\mathrm{K}$ to soluble $\mathrm{K}$ forms in the soil.

Table 3. Effect of integrated nutrient management on the macro nutrient status of tomato

\begin{tabular}{|c|c|c|c|}
\hline Treatments & Available N (kg/ha) & Available P (kg/ha) & $\begin{array}{l}\text { Available K } \\
\text { (kg/ha) }\end{array}$ \\
\hline $\mathrm{T}_{1}(20 \mathrm{mt} / \mathrm{ha})$ & 323.30 & 71.00 & 174.90 \\
\hline $\mathrm{T}_{2}(1 / 2 \mathrm{NPK}+30 \mathrm{mt} / \mathrm{ha} \mathrm{FYM})$ & 350.80 & 88.70 & 193.60 \\
\hline $\mathrm{T}_{3}(3 / 4 \mathrm{NPK}+25 \mathrm{mt} / \mathrm{ha}$ & 363.60 & 90.50 & 203.60 \\
\hline $\mathrm{T}_{4}$ (10 MT/ha Vermicompost) & 331.70 & 73.40 & 179.90 \\
\hline $\mathrm{T}_{5}(1 / 2 \mathrm{NPK}+15 \mathrm{mt} / \mathrm{ha}$ Vermicompost & 382.80 & 100.40 & 230.80 \\
\hline $\mathrm{T}_{6}(3 / 4 \mathrm{NPK}+12.5 \mathrm{mt} / \mathrm{ha}$ Vermicompost & 352.80 & 96.40 & 216.30 \\
\hline $\begin{array}{l}\mathrm{T}_{7}(16.66 \mathrm{mt} / \mathrm{ha} \mathrm{FYM}+8.33 \mathrm{mt} / \mathrm{ha} \text { Vermicompost } \\
+\mathrm{NPK})\end{array}$ & 366.10 & 93.30 & 212.70 \\
\hline $\mathrm{T}_{8}($ Recommended NPK (100: 80: $60 \mathrm{~kg} / \mathrm{ha})$ & 340.00 & 89.30 & 184.10 \\
\hline $\mathrm{T}_{9}$ (Control) & 269.40 & 65.90 & 147.20 \\
\hline $\mathrm{CD}(0.05)$ & 26.12 & 5.96 & 25.17 \\
\hline
\end{tabular}


The integration of organic manures in combination with inorganic fertilizers was found significant in improving the overall plant growth, yield and soil macro nutrient status than the sole application of either of these nutrients. The combined use of organic and inorganic nutrients result in solubilization of plant nutrients which lead to increased up take of NPK. Mixing of organic and inorganic nutrients reduce the nutrient losses, improving the fertilizer use efficiency thus increasing the soil nutrient availability.

\section{Acknowledgements}

We are thankful to Dr. Binayak P. Rajbhandari, Executive Director of Himalayan College of Agricultural Sciences and Technology (HICAST) for providing the field and laboratory facilities for this research.

\section{References}

Alam, M.N. 2006. Effect of vermicompost and some chemical fertilizers on yield and yield components of selective vegetable crops. Ph.D. Thesis, Faculty of Agriculture, University of Rajshahi, Bangladesh, pp: 122-176.

VDD. 2009. Annual progressive report. Vegetable Development Directorate, Khumaltar, Lalitpur.

Azad, A.K. 2000. Effects of plant spacing, source of nutrients and mulching on growth and yield of cabbage. M. Sc. Thesis. Department of Horticulture, Bangladesh Agriculture University Mymensingh, pp. 15-40.

Bahadur, A., J. Singh and K.P. Singh. 2004. Response of cabbage to organic manures and biofertilizers. Indian Journal. of Horiculture 61(3):278-279.

FAO. 2002. FAO production year book. Basic Data Unit of Statistics Division, FAO, Italy, 54: 139-141,2002.

FAO. 2003. FAO Bulletin of Statistics 3(2):87-88.
Hanway, J.J. and H. Heidal. 1952. Soil analysis method as used in Low State College Soil Testing Laboratory. Lowa Aric. 57:1-31.

Jackson, M.L. 1975. Soil chemical analysis. Practice Hall of India, New Delhi.

Kabir, H.T. 1998. Effect of sources of nutrients on yield and quality of cabbage. M. Sc. Thesis. Department of Horticulture. Bangladesh Agriculture University. Mymensingh, pp. 13-39.

Kumar, A., S. Sharma and S. Mishra. 2009. Application of farmyard manure and vermicompost on vegetative and generative characteristics of Jatropha curcas. Journal of Phytopathology 1(4): 206-222.

Kumar, P and S. K. Sharma. 2004. Integrated nutrient management for sustainable cabbage- tomato cropping sequence under mid hill conditions of Himachal Pradesh. Indian Journal of Horticulture 61(4): 331-334.

Kumaran, S., S. Natarajan and S. Thamburaj. 1995. Effect of organic and inorganic fertilizers on growth, yield and quality of tomato. South Indian Horticulture 46 (3 \&4):203-205.

Olsen, S.R., C.V. Cole, F.S. Watanabe, L.A. Dean. 1954. Estimation of available phosphorus in soils by extraction with sodium bicarbonate. Circular, US Department of Agriculture, pp. 939.

Prasad, B. and J. Rokima. 1992. Changes in available nutrient status of calcareous soil as influneced by manures, fertilizers and biofertilizers. Journal of Indian Society Soil Science 39:783-785.

Renuka, B. and C. Ravi Shankar. 1998. Effect of organic manures on growth and yield of tomato. South Indian Horticulture 49:216-217.

Subbiah, K., J. Helkiah, V. Ravikumar and C.V. Rajagopal. 1982. Effect of the combined application of organic and inorganic fertilizers on yield and nutrient uptake of chilli. South Indian Horticulture 30:45-47. 
Nepal Journal of Science and Technology 12 (2011) 23-28 